\title{
Üniversite Öğrencilerinde Özgecilik ve Mükemmeliyetçilik Anlayışı Arasındaki İlişkinin İncelenmesi
}

DOI: 10.26466/opus.580182

\author{
Kamala Khalınbaylı ${ }^{* *}$ - Besra Taş ${ }^{* *}$ \\ * Öğr. Gör., İstanbul Gelişim Üniversitesi/ İstanbul/Türkiye \\ E-Posta: kkhalinbayli@gelisim.edu.tr \\ ORCID: 0000-0002-3929-1269 \\ ** Dr. Öğr. Üyesi, İstanbul Sabahattin Zaim Üniversitesi/ İstanbul/Türkiye \\ E-Posta: besra.tas@izu.edu.tr \\ ORCID: $0000-0002-1273-4429$
}

$\ddot{O} z$

Bu araştırmada üniversite öğrencilerinde özgecilik ve mükemmeliyetçilik anlayışları arasındaki iliş̧inin incelenmesi amaçlanmıştır. Araştırma İstanbul ilinde farklı devlet ve özel üniversitelerinde öğrenim görmekte olan 250'si kız, 250' si erkek olan toplam 500 üniversite öğrencisi ile gerçekleştirilmiştir. Katılllımcıların özgecilik düzeylerine ilişkin veriler Özgecilik Ölçeği, mükemmeliyetçilik düzeylerinin belirlenmesinde Kendini Mükemmeliyetçi Gösterme Ölçeği ve kişisel özelliklere ilişkin veriler araştırmacı tarafından hazırlanan Kişisel Bilgi Formu kullanılarak elde edilmiştir. Regresyon analizinde üniversite öğrencilerinde özgecilik düzeylerinin alt boyutlarından alınan puanlar yordanan değişken (gönüllü faaliyetlere katılım, maddi yardımı, travmatik durumlarda yardımı, yaşll/ hastalara yardımı,fiziksel güce dayalı yardımı, eğitim sürecinde yardımı, yakınlı duygusundan kaynaklanan yardımı), mükemmeliyetçi kendini göstermenin alt boyutlarından (mükemmeliyetçi öz-tanıtım, kusur saklama ve kusuru açığa vurmama) alınan puanlar yordayıcı değişken olarak ele alınmıştır. Üniversite öğrencilerinde özgecilik anlayışının cinsiyete ve yaşa göre farklılaşıp farklılaşmadı̆̆ını incelemek için tek yönlü varyans analizi ve $T$ testi analizleri yapılmıştır. Araştırma sonuçlarına göre, üniversite öğrencilerinde özgecilik davranışı ve mükemmeliyetçilik arasında anlamlı ilişkilerin olduğu tespit edilmiştir. Ayrıca kadınların erkeklerden daha fazla özgeci davranışta bulundukları, yaşı küçük olan üniversite öğrencilerinin büyük olanlara göre daha az özgeci davranış gösterdikleri de tespit edilmiştir.

Anahtar Kelimeler: Özgecilik, Mükemmeliyetçilik, Üniversite Öğrencileri 


\title{
Reviewing of The Relationship Between Altruism And Perfectionism Mentality Among University Students
}

\begin{abstract}
In this research, it is aimed to review the relationship between altruism and perfectionism mentality among university students. The research has been conducted among 250 girls, 250 boys, in total 500 university students who have studied in different public and private universities in Istanbul. The data related to the attendant's altruism levels are obtained by using Altruism Scale, their perfectionism levels were determined by using the Perfectionistic Self-Presentation Scale and data related to personal characteristics was obtained by using Personal Information Form that was issued by the researcher. In regression analysis, points, that are taken from the sub-dimension of the altruism levels among the university students are obtained as dependent variable (attendance to voluntary activities, financial supports, help in the traumatic situations, help for old patient people, help based on physical force, help during the education period, help arisen from feeling closeness), points that are taken from the subdimension (perfectionist self-presentation, nondisplay of imperfection and nondisclosure of imperfection) of the perfectionistic self-presentation are obtained as a predictor variable. One way variance analysis and T-test analyses were made to review altruism mentality among the university students whether it becomes different or not according to gender, age, the average income of the family, people of which living together with, family-style that she/he has grown up. According to the research results, it has been determined that there are significant relationships between an altruism act and perfectionism among university students. Also, it has been determined that a woman has been acting more altruist than a man, juniority university students have been acting less altruist than the older ones.
\end{abstract}

Keywords: Altruism, Perfectionism, University Students 


\section{Giriş}

Özgecilik, insanların birbirine yardımcı olma emeliyle hareket ettiği olumlu sosyal davranışlardan biridir. Özgecilik, kendi güvenliğini, çıkarını gözetmeksizin gösterilen bir davranış olarak ortaya çıkmaktadır (Gerrig, Zimbardo, 2012). Özgecilik, karşılı̆̆ında bir bedel ödemek gerektiğinde bile başkasına yardım etme isteğidir (Aronson,Wilson, Akert, 2012).

Dini duygular, ahlaki duygular, iyilikseverlik gibi kavramlar kişinin toplumdaki diğer bireyleri düşünerek onlara gönüllü yardım edebilmesi konusunda güdü oluşturabilmekte ve "özgecilik" kavramı çerçevesinde incelenebilmektedir (Palaz, Boz, 2008).

Mükemmeliyetçi kişiler olayları ya tamamen doğru ya da tamamen yanlış olarak görmekte, seçici algılla olumsuz detayları hemen fark edip bu detayları felaket olarak yorumlamakta ve bunun sonucunda erteleme ya da kaçma davranışı göstermektedirler (Antony ve Swinson, 2000). Mükemmeliyetçi kişilik özelliklerinden olan düzenlilik, hata yapmaktan korkmak, hata yapmamaya odaklanmak; başarıyı değil, başarısız olmamayı amaç edinmek, ebeveynlerinin eleştirel ve olumsuz tutumundan kaçınan çocuklarda daha çok görülmektedir (Özgüngör, 2003).

Mükemmeliyetçiliğin kimlik sorunu olduğu düşünülse de, aslında bu bir ilişki sorunudur ve kişi "diğer insanlar" tarafından yargılanmaktan korkmaktadır (Bolat, 2018).

Başkaları yönelimli mükemmeliyetçilik, HEXACO' (HEXACO- Lee ve Ashton (2004) tarafından geliştirilen ve kişilik özelliklerini ölçmeyi amaçlayan ölçek) nun duygusallığı, kabul edilirliği ve özgeciliği ile benzersiz negatif ilişkiler göstermiştir. $\mathrm{Bu}$, başkalarına yönelik mükemmeliyetçilerin diğer insanlara göre daha az duygusal, kabul edici ve şefkatli olduklarını düşündürecek bir sonuçtur. Kendi yönelimli mükemmeliyetçilik ise, kendine yönelik mükemmeliyetçilerin, ihtiyacı olanlara karşı diğer insanlardan daha şefkatli olduğunu düşündürecek şekilde özgecilikle benzersiz pozitif ilişkiler göstermiştir (Stoeber, 2015).

Yapıcı mükemmeliyetçilik ve tutku kendi içinde özgecil özellikleri barındırmaktadır. Yapıcı mükemmeliyetçinin özgeciliği doğrudan ya da 
dolaylı olarak kendi menfaat ve beklentisi için çalışan kişiye yarar sağlamaktadır (Vyunova, Larskikh, Strebkova , 2014).

Kanadalı araştırmacılara göre, sosyal olarak dayatılmış mükemmeliyetçilik diğer insanların standartlarını ve beklentilerini karşılama ihtiyacını kendinde yansıtmaktadır. Bu kişiler özgecilik özelliklerinin tezahüründe diğer insanlara sürekli yardımda bulunmakta, ödül olaraksa "takdir" görmeyi beklemektedirler ( Ermilova, 2015).

\section{Yöntem}

Araştırmanın bu bölümünde araştırmanın modeli, araştırma grubu, veri toplama araçları ile verilerin toplanması ve verilerin analizi hakkında bilgiler verilmiştir.

\section{Araştırmanın Modeli}

Üniversite öğrencilerinde özgecilik ve mükemmeliyetçilik arasındaki ilişkileri ortaya koymak ve bununla beraber bu iki değişkenin çeşitli sosyo-demografik değişkenlere göre anlamlı bir şekilde farklılaşıp farklılaşmadığını belirlemeye yönelik yapılan bu çalışma; genel tarama modellerinden ilişkisel tarama modeline göre desenlenmiştir. Tarama modelleri hali hazırda veya geçmişte var olan bir durumu var olduğu şekilde betimlemeyi hedefleyen araştırma yaklaşımıdır. Bu araştırma modelinin bir diğer önemli özelliği de var olan durumu değiştirmeksizin olan durumu gözlemlemektir (Karasar,2011). Üniversite öğrencilerinin mükemmeliyetçi kendini gösterme özelliklerinin, onların özgecilik düzeylerini nasıl yordadığı incelenmektedir. Bunun yanı sıra özgecilik davranışının çeşitli demografik değişkenlere göre değişiminin incelenmesi amaçlanmıştır.

\section{Araştırma grubu}

$\mathrm{Bu}$ araştırmanın çalışma grubunu, 2017-2018 Eğitim-Öğretim yılında Türkiye, İstanbul ilinde 5'i devlet, 8'i özel olmak üzere farklı üniversitelerde 
ve farklı bölümlerde öğrenim görmekte olan 250'si kız ve 250'si erkek olmak üzere toplam 500 öğrenci oluşturmuştur.

\section{Veri Toplama Araçları}

Bu çalışmada "Kişisel Bilgi Formu", “Özgecilik Ölçeği” ve "Mükemmeliyetçi Kendini Gösterme Ölçeği" veri toplama aracı olarak kullanılmıştır. Veri toplama araçlarına ait detaylı bilgi aşağıda belirtilmiştir.

1. Kişisel Bilgi Formu: Üniversite öğrencileri ile ilgili çeşitli değişkenler hakkında bilgi toplamak amacıyla araştırmacı tarafından geliştirilmiştir. Kişisel bilgi formunda cinsiyet, yaş, fakülte, bölümle ilgili bilgiler yer almaktadır. Etik kurallar ve gerçekçi yanıtlar alabilmek için araştırma esnasında öğrencilere kimlik bilgilerini içeren sorular yöneltilmemiştir.

2. Özgecilik Ölçeği: Ümmet, Ekşi, Otrar (2013) tarafından Türkçe güvenirlik ve geçerlik çalışması yapılan ölçek, kültürel yapıya uygun olarak kişilerin özgecilik davranışlarını ölçmede kullanılmaktadır. Ölçeğin geçerlik ve güvenirlik çalışmaları, Marmara Üniversitesi'nin farklı fakültelerinde öğrenim gören 336'sı kadın, 248'i erkek ve yaş ortalaması 22.90 olan toplam 584 öğrencinin katılımıla gerçekleştirilmiştir. Ölçek geliştirme çalışmasında açımlayıcı faktör analizi kullanılmış, madde ayırt edicilikleri belirlenmiş, kriter geçerliği çalışması yapılmış ve Cronbach Alpha güvenirlik sayısı hesaplanmıştır. Çalışmanın sonunda toplam varyansın 51.82'sini açıklayan 38 maddeden ve 7 alt boyuttan (gönüllü faaliyetlere katılma, maddi yardım, travmatik durumlarda yapılan yardım, yaşl1/hastalara yapılan yardım, fiziksel güce dayalı yardım, eğitim sürecinde yardım, yakınlık duygusundan kaynaklanan yardım) oluşan bir ölçek elde edilmiştir. Ölçeğin alt boyutlara ve toplamına dair Cronbach Alpha güvenirlik sayıları hesaplanmış, toplam Cronbach Alpha değerinin .81 olduğu saptanmıştır. 
Bu çalışma kapsamında özgecilik ölçeğinin güvenirlik katsayısı 93 olarak hesaplanmıştır.

3. Mükemmeliyetçi Kendini Gösterme Ölçeği: Balc1, Kıral, Kalafat ve Boysan (2009) tarafından geliştirilen Kendini Mükemmeliyetçi Gösterme Ölçeği, türk toplumunda mükemmeliyetçilik eğilimi yüksek olan kişilerde kendini çok fazla öne çıkarma ve onay alma ihtiyacı davranışının altında yatan faktörleri ve beklenen olumsuz sonuçları değerlendirme imkanı verecektir. Mükemmeliyetçi ÖzTanıtım, Kusur Saklama ve Kusuru Açı̆̆a Vurmama Mükemmeliyetçi Kendini Gösterme ölçeğinin alt boyutlarıdır. KMGÖ'nin türk örneklemini üniversitede lisans eğitimi almakta olan 271 öğrenci oluşturmuştur. Ölçeğin türk örneklemindeki geçerliliği doğrulayıc1 faktör analizi kullanılarak test edilmiştir. Ölçeğin iç tutarlılığ 1 Cronbach alfa katsayısı hesaplanarak değerlendirilmiş ve ölçme aracından elde edilen iç tutarlık değerinin çok yüksek olduğu saptanmıştır. Ölçeğe ilişkin hesapalanan iç tutuarlılık değerinin $\alpha=0.80$ olduğu saptanmıştır. Benzer bir biçimde ölçeğin 15 günlük test tekrar test korelasyonunun da yüksek olduğu bulunmuş, r= 0.82 olarak hesaplanmıştır.

Bu çalışma kapsamında kendini mükemmeliyetçi gösterme ölçeğinin güvenirlik katsayısı .84 olarak hesaplanmıştır.

\section{Veri Toplama İşlemi}

Araştırma, İstanbul ilinde farklı devlet ve özel üniversitelerinde öğrenim gören üniversite öğrencileri ile yapılmıştır. Araştırmada kullanılan Kişisel Bilgi Formu ile birlikte Özgecilik Ölçeği ve Mükemmeliyetçi Kendini Gösterme Ölçeği 2017-2018 akademik yılı ikinci dönemi nisan-mayıs ayları içerisinde uygulanmıştır. Önce araştırmanın amacı hakkında kısa bir bilgi verilmiş, sonra ise uygulama için uygun saatler tespit edilmiştir.Ölçeklerin doldurulması 15-20 dakika arasında bir sürede tamamlanmıştır. 


\section{Verilerin Analizi}

Araştırma sorularına bağlı olarak verilerin analizinde çoklu regresyon analizi (enter), T testi, tek yönlü varyans analiz ve frekans dağılımları, aritmetik ortalama ve standart sapma gibi betimsel veriler kullanılmıştır. Araştırmanın 1. Sorusuna cevap aramak için çoklu regresyon analizi yapılmıştır. Regresyon analizinde üniversite öğrencilerinde özgecilik düzeylerinin alt boyutlarından alınan puanlar yordanan değişken (gönüllü faaliyetlere katılım, maddi yardımı, travmatik durumlarda yardımı, yaşlı/ hastalara yardımı, fiziksel güce dayalı yardımı, eğitim sürecinde yardımı, yakınlık duygusundan kaynaklanan yardım), mükemmeliyetçi kendini göstermenin alt boyutlarından (mükemmeliyetçi öz-tanıtım, kusur saklama ve kusuru açı̆̆a vurmama) alınan puanlar yordayıcı değişken olarak ele alınmıştır. Üniversite öğrencilerinde özgecilik anlayışının cinsiyete, yaşa göre farklılaşıp farklılaşmadığını incelemek için tek yönlü varyans analizi ve $T$ testi analizleri yapılmıştır.

Çalışmada analizlere geçilmeden önce veriler incelenip veri analize uygun hale getirilmiştir. Bunun için ilk olarak kayıp verilere bakılmış ve kayıp veri bulunmadığı tespit edilmiştir. Daha sonra verilerin regresyonun şartlarından olan çoklu doğrusal bağıntı, normal dağılım ve uç değerler incelenmiştir.

Normal dağılım için basıklık ve çarpıklığın -2 ile +2 aralığında olması gerektiği belirtilmiş ve mevcut çalışmada bu şartın sağlandığı görülmüştür (Akbulut, 2010; George, ve Mallery, 2016; Tabachnick ve Fidell, 2013). Değişkenler ile ilgili çoklu doğrusal bağlantıyı incelemek için Tolerans değerlerinin .10 dan küçük ve VIF değerlerinin ise 1'dan büyük olmasının şart olduğu mevcut çalışmada verilerinin bu şartı sağladığı tespit edilmiştir (Field,2013). Uç değerler incelemek için mahalanobis uzaklık değerlerine bakılmış uzaklık (degerler 0.22 ile 21.66 arasında) ve veri grubunda uç değer olmadığı anlaşımıştır. Otokorelasyon sorunun olup olmadığını tespit etmek için Durbin-Watson değerinin 1-3 arasında olması (Akbulut, 2010) ölçütü dikkate alınmıştır.

Varyans analizleri ve $\mathrm{T}$ testinde varyansların homojenligi şartının saglanıp saglanmadıgını test etmek için Levene F testine bakılmıştır. Bu te- 
stler sonucunda elde edilen puanlarda anlamlı bir farklılık görüldüğ̈̈ durumlarda, bu farkı ortaya koymak için varyansların eşteş olduğu durumlarda post hoc testlerinden Tukey, olmadığ 1 durumlarda ise Tamhane kullanılmıştır. Ayrıca analizlerin etki büyüklükleri de rapor edilmiş ve Cohen (1988)'e göre yorumlanmiştır.

Çalışmanın verileri $\mathrm{R}$ istatistik paket programı, (version 3.5.1, 2018-0702) (https://www.r-project.org) arac1lyyla analiz edilmiş ve anlamlılık düzeyi .05 olarak belirlenmiştir.

\section{Bulgular}

Bu bölümde çalışmada elde edilen bulgular sunulmuştur. Bu bağlamda bu bölümde sırasıyla ilk olarak üniversite öğrencilerinin özgecilik düzeyleri ve mükemmeliyetçi kendini gösterme özelliklerine ilişkin betimsel değerler ortaya konulmaktadır. Bundan sonra çalışmaya dahil edilen bireylerin özgecilik düzeylerinin mükemmeliyetçi kendini gösterme özellikleri tarafından anlamlı düzeyde yordanıp yordanmadığı ortaya konulmuştur. Daha sonra üniversite öğrencilerinde özgecilik anlayışı; cinsiyete göre, yaşa göre farklılaşma düzeyleri ortaya konulmuştur.

\section{Üniversite Öğrencilerinde Özgecilik Anlayışının Cinsiyete Göre Incelenmesine İlişkin Bulgular}

Çalışmada, üniversite öğrencilerinde özgecilik anlayışının cinsiyete göre farklılaşıp farklılaşmadığını belirlemek amaçlanmıştır. Bu çerçevede üniversite öğrencilerinde özgecilik anlayışının cinsiyete göre incelenmesine yönelik $\mathrm{t}$ testi sonuçları, puanlarının ortalamaları ve standart sapmaları belirlenmiş ve Tablo 1'de sunulmuştur. Analizde Levene testi sonuçlarına göre varyansların eşteş olduğu tespit edilmiştir.

Tablo 1. Üniversite Öğrencilerinde Özgecilik Anlayışı T Testi Sonuçları

\begin{tabular}{llllllllll}
\hline & cinsiyet & $\mathbf{N}$ & Ortalama & Ss & Sh & $\mathbf{t}$ & Sd & $\mathbf{P}$ & $\begin{array}{l}\text { Cohen } \\
\mathbf{d}\end{array}$ \\
\hline Özgecilik & Erkek & 250 & 139.9 & 22.7 & 1.43 & -5.65 & 498 & .001 & -0.506 \\
& Kadın & 250 & 150.2 & 17.6 & 1.11 & & & & \\
\hline
\end{tabular}


Tablo 1'de görüldüğü gibi üniversite öğrencilerinin özgecilik düzeyleri incelendiğinde, cinsiyete göre kadınlar ve erkekler arasında anlamlı bir farklılık olduğu görülmektedir ( $\mathrm{t}(498)=-5.65, \mathrm{p}<, 001)$. Buna göre kadınların da özgecilik davranışı ( $X=150.2$, Ss=17.6) erkeklere $(X=139.9, S s=22.7)$ göre daha yüksek olduğu söylenebilir. Elde edilen sonucun etki büyüklüğünün orta düzeyde anlamlı olduğu tespit edilmiştir (Cohen d=-0.506).

\section{Üniversite Öğrencilerinde Özgecilik Anlayışının Yaşa Göre İncelenme- sine İlişkin Bulgular}

Üniversite öğrencilerinde özgecilik anlayışının yaş arttıkça farklılaşıp farklılaşmadığını belirlemek amaçlanmıştır. Bu çerçevede üniversite öğrencilerinde özgecilik anlayışının yaşa göre incelenmesine yönelik puanlarının ortalamaları ve standart sapmaları belirlenmiş ve Tablo 2'de sunulmuştur.

Tablo 2. Üniversite Öğrencilerinde Özgecilik Anlayışının Yaşa Göre Dağılımları

\begin{tabular}{llll}
\hline Yaş & Ortalama & Ss & N \\
\hline $18-20$ & 141.5 & 22.44 & 202 \\
$21-23$ & 147.8 & 18.46 & 247 \\
$24-26$ & 141.9 & 25.51 & 36 \\
27 ve üstü & 156.3 & 18.08 & 15 \\
\hline
\end{tabular}

Elde edilen bu bulgularından üniversite öğrencilerinde özgecilik anlayışlarında gözlenen ortalamaların anlamlı bir biçimde farklılaşıp farklılaşmadığını belirlemek için tek yönlü varyans analizi yapılmıştır. Bu amaç doğrultusunda, ilk önce puanların varyanslarının homojen olduğu Levene testi $[\mathrm{F}(3,496)=1.746, \mathrm{p}=.15]$ ile belirlenmiş olup daha sonra tek

yönlü varyans analizi uygulanmıştır. Üniversite öğrencilerinde özgecilik anlayışlarının varyans analizine ilişkin sonuçlar Tablo 3'te sunulmuştur.

Tablo 3. Üniversite Öğrencilerinde Özgecilik Anlayışı Düzeylerine İlişkin Varyans Analizi Sonuçları

\begin{tabular}{lllllll}
\hline Varyansın kaynağ1 & KT & Sd & KO & F & P & $\boldsymbol{\eta}^{2}$ \\
\hline Yaş & 6685 & 3 & 2228.4 & 5.204 & 0.002 & 0.031 \\
Sabit & 212404 & 496 & 428.2 & & & \\
\hline
\end{tabular}


Tablo 3'te yer alan bulgulara göre üniversite öğrencilerinde özgecilik düzeylerinde yaşa göre gruplar arasında önemli bir farklılık bulunmaktadır. Bu farklılık Cohen'e (1988) göre yorumlandığında etki büyüklüğünün küçük düzeyde olduğu görülmektedir $\left(\eta^{2}=0.031\right)$. Bu farkın kaynağını tespit etmek amaciyla gerçekleştirilen tukey testi sonuçları tablo $4^{\prime}$ te sunulmuştur.

Tablo 4. Üniversite Öğrencilerinde Yaşa Göre Özgecilik Düzeylerine İlişkin Tukey Testi Sonuçları

\begin{tabular}{llllll}
\hline Yaş & & $\begin{array}{l}\text { Ortalama } \\
\text { fark1 }\end{array}$ & Sh & T & ptukey \\
\hline $18-20$ & $21-23$ & $\mathbf{- 6 . 3 0 5}$ & $\mathbf{1 . 9 6 3}$ & $\mathbf{- 3 . 2 1 2}$ & $\mathbf{0 . 0 0 7}$ \\
& $24-26$ & -0.436 & 3.744 & -0.117 & 0.999 \\
& 27 ve üstü & $\mathbf{- 1 4 . 8 5 3}$ & $\mathbf{5 . 5 3 8}$ & $\mathbf{- 2 . 6 8 2}$ & $\mathbf{0 . 0 3 3}$ \\
\hline $21-23$ & $24-26$ & 5.869 & 3.692 & 1.590 & 0.359 \\
& 27 ve üstü & -8.548 & 5.503 & -1.553 & 0.380 \\
\hline $24-26$ & 27 ve üstü & -14.417 & 6.360 & -2.267 & 0.095 \\
\hline
\end{tabular}

Tablo 4'te görüldüğü gibi, araştırmaya katılan üniversite öğrencilerinde 18-20 yaş özgecilik puanı ortalaması ( $X=141.5$ ) ile 21-23 yaş arası öğrencilerin puanı ortalaması $(X=147.8)$ ve 27 ve üstü öğrencilerin puan ortalaması ( $X=156.3$ ) arasındaki fark anlamlı bulunmuştur. Bu bulgular çerçevesinde 21-23 yaşları arasında bulunan üniversite öğrencilerinde özgecilik davranışı 18-20 yaş arasından daha yüksektir. Benzer şekilde 27 yaş ve üstü öğrencilerde özgecilik davranışı 18-20 yaş arasındakilerden daha yüksektir.

\section{Değişkenlere İlişkin Betimsel İstatistikler ve Değişkenler Arasında Pearson Korelasyon Katsayılar}

Üniversite öğrencilerinin özgecilik ve alt boyutları olan gönüllü faaliyetlere katılım, maddi yardımı, travmatik durumlarda yardımı, yaşlı/ hastalara yardımı, fiziksel güce dayalı yardımı, eğitim sürecinde yardımı, yakınlık duygusundan kaynaklanan yardımı ile mükemmeliyetçi kendini gösterme ve alt boyutları olan mükemmeliyetçi öz-tanıtım, kusur saklama ve kusuru açığa vurmama değişkenlerine ilişkin betimsel istatistikler tablo 5’5e gösterilmiştir. 
Tablo 5. Değişkenlerine İlişkin Betimsel İstatistikler (N:500)

\begin{tabular}{lllllllllllll}
\hline Değişkenler & $\mathbf{1}$ & $\mathbf{2}$ & $\mathbf{3}$ & $\mathbf{4}$ & $\mathbf{5}$ & $\mathbf{6}$ & $\mathbf{7}$ & $\mathbf{8}$ & $\mathbf{9}$ & $\mathbf{1 0}$ & $\mathbf{1 1}$ & $\mathbf{1 2}$ \\
\hline $\begin{array}{l}\text { Geçerli kişi } \\
\text { sayısı }\end{array}$ & 500 & 500 & 500 & 500 & 500 & 500 & 500 & 500 & 500 & 500 & 500 & 500 \\
\hline Ortalama & 145.1 & 109.4 & 39.84 & 37.44 & 29.08 & 24.87 & 23.08 & 24.26 & 15.59 & 18.65 & 19.12 & 19.50 \\
\hline $\begin{array}{l}\text { Standart } \\
\text { sapma }\end{array}$ & 20.95 & 21.59 & 10.25 & 8.818 & 6.252 & 5.462 & 4.328 & 3.711 & 2.975 & 3.757 & 3.103 & 3.419 \\
\hline Varyans & 439.1 & 466.0 & 105.1 & 77.76 & 39.08 & 29.83 & 18.73 & 13.77 & 8.848 & 14.12 & 9.630 & 11.69 \\
\hline Çarpıklık & -0.86 & -0.15 & -0.04 & -0.28 & -0.04 & -0.70 & -0.97 & -0.94 & -0.97 & -0.79 & -0.74 & -0.95 \\
\hline Basıklık & 1.742 & 0.12 & -0.51 & 0.20 & -0.01 & 0.46 & 1.40 & 2.00 & 1.55 & 1.03 & 1.41 & 1.20 \\
\hline $\begin{array}{l}\text { En düşük } \\
\text { değer }\end{array}$ & 54 & 36 & 13 & 9 & 9 & 7 & 6 & 6 & 4 & 5 & 5 & 7 \\
\hline $\begin{array}{l}\text { En yüksek } \\
\text { değer }\end{array}$ & 188 & 174 & 66 & 62 & 47 & 35 & 30 & 30 & 20 & 25 & 25 & 25 \\
\hline
\end{tabular}

1.özgecilik, 2.mükemmeliyetçi kendini gösterme, 3.mükemmeliyetçi öz-tanıtım, 4.kusur saklama, 5.kusuru açığa vurmama, 6.gönüllü faaliyetlere katılım, 7.maddi yardım, 8.travmatik durumlarda yardım, 9.yaşlı/ hastalara yardım 10.fiziksel güce dayalı yardım 11.eğitim sürecinde yardım, 12.yakınlık duygusundan kaynaklanan yardım.

Tablo 5 'te değişkenlere ilişkin dağglımlar sunulmuştur. Regresyon analizi, T testi ve varyans analizlerine geçilmeden önce verilerin normal dağılım gösterip göstermediğine çarpıklık-basıklık değerleri incelenerek karar verilmiştir. Tablo 5 'te görüleceği üzere değişkenlerin neredeyse tamamının çarpıklık-basıklık değerlerinin +2 ile -2 arasında olduğu görülmektedir. Verilerin normal dağılım şartını sağlaması için çarpıklık-basıklık değerlerinin +2 ile -2 arasında olması gerektiği belirtildiğinden (Tabachnick ve Fidell, 2013), bu çalışmadaki verilerin normal sınırlar içinde dağılım gösterdiği söylenebilir. Çalışmadaki tüm değişkenler arasındaki ilişkileri ortaya koymak üzere değişkenler arasındaki pearson korelasyon katsayıları hesaplanmış ve sonuçlar Tablo 6' da gösterilmiştir.

Tablo 6'da görüleceği üzere değişkenler arasındaki korelasyon katsayıları .11 ile .88 arasında değişmektedir. Araştırmanın bağımsız değişkenlerinden olan mükemmeliyetçi kendini gösterme ile bağımlı değişken yakınlık duygusundan kaynaklanan yardım arasında $(\mathrm{r}=.13, \mathrm{p}<.01)$ pozitif ilişki bulunurken mükemmeliyetçi kendini gösterme ile diğer bağımlı değişkenler arasında herhangi bir ilişki tespit edilememiştir. 
Tablo 6. Değişkenler Arasındaki Pearson Korelasyon Katsayıları

\begin{tabular}{|c|c|c|c|c|c|c|c|c|c|c|c|c|}
\hline Değişkenler & 1 & 2 & 3 & 4 & 5 & 6 & 7 & 8 & 9 & 10 & 11 & 12 \\
\hline 1.Özgecilik & 1 & & & & & & & & & & & \\
\hline 2.Gönülü & & & & & & & & & & & & \\
\hline Faaliyetlere & $.81^{* * *}$ & 1 & & & & & & & & & & \\
\hline Katılım & & & & & & & & & & & & \\
\hline 3.Maddi yardım & $.79 * * *$ & $.64^{* * *}$ & 1 & & & & & & & & & \\
\hline $\begin{array}{l}\text { 4.Travmatik } \\
\text { durumlarda } \\
\text { yardım }\end{array}$ & $.77^{* * *}$ & $.51^{* * *}$ & $.51^{* * *}$ & 1 & & & & & & & & \\
\hline $\begin{array}{l}\text { 5.Yaşlı/ hastalara } \\
\text { yardım }\end{array}$ & $.77^{* * *}$ & $.55^{* * *}$ & $.53^{* * *}$ & .57 & 1 & & & & & & & \\
\hline $\begin{array}{l}\text { 6.Fiziksel güce } \\
\text { dayalı } \\
\text { yardım }\end{array}$ & $.79^{* * *}$ & $.55^{* * *}$ & $.56^{* * *}$ & $.52^{* * *}$ & $.58^{* * *}$ & 1 & & & & & & \\
\hline $\begin{array}{l}\text { 7.Eğitim sürecinde } \\
\text { Yardım }\end{array}$ & $.74^{* * *}$ & $.50^{* * *}$ & $.46^{* * *}$ & $.58^{* * *}$ & $.59^{* * *}$ & $.52^{* * *}$ & 1 & & & & & \\
\hline $\begin{array}{l}\text { 8.Yakınlık } \\
\text { duygusundan } \\
\text { kaynaklanan } \\
\text { yardım }\end{array}$ & $.75^{* * *}$ & $.46^{* * *}$ & $.52^{* * *}$ & $.58^{* * *}$ & $.49^{* * *}$ & $.61^{* * *}$ & $.54^{* *}$ & 1 & & & & \\
\hline $\begin{array}{l}\text { 9.Mükemmeliyetçi } \\
\text { kendini gösterme }\end{array}$ & .05 & .05 & .01 & -.03 & .01 & .04 & .04 & $.13^{* *}$ & 1 & & & \\
\hline 10.Öz-Tanıtım & -.03 & -.01 & -.06 & $-.09^{*}$ & -.05 & -.03 & -.01 & .06 & $.87^{* * *}$ & 1 & & \\
\hline 11.Kusur saklama & .06 & .03 & .02 & -.02 & -.01 & .07 & .05 & $.19^{* * *}$ & $.88^{* * *}$ & $.67^{* * *}$ & 1 & \\
\hline $\begin{array}{l}\text { 12.Kusuru açığa } \\
\text { vurmama }\end{array}$ & $.14^{* *}$ & $.13^{* *}$ & $.12^{* *}$ & .06 & $.14^{* *}$ & $.14^{* *}$ & $.11^{*}$ & .08 & $.71^{* * *}$ & $.41^{* * *}$ & $.50^{* * *}$ & 1 \\
\hline
\end{tabular}

Araştırmanın diğer bağımsız değişkenlerinden olan mükemmeliyetçi öz-tanıtım ile travmatik durumlarda yardım $(\mathrm{r}=-.09, \mathrm{p}<.05)$ arasında yine negatif yönde bir ilişki bulunurken diğer bağımlı değişkenler ile arasında herhangi bir ilişki tespit edilememiştir. Bir diğer bağımsız değişken olan kusur saklama ile bağımlı değişken olan yakınlık duygusundan kaynaklanan yardım arasında $(\mathrm{r}=.19, \mathrm{p}<.001)$ pozitif ilişki bulunurken diğer bağımlı değişkenler ile arasında herhangi bir ilişki tespit edilememiştir. Son olarak araştırmanın son bağımsız değişkenlerinden olan kusuru açığa vurmama ile özgecilik $(\mathrm{r}=.14, \mathrm{p}<.01)$, gönüllü faaliyetlere katılım $(\mathrm{r}=$ $.13, \mathrm{p}<.01)$, maddi yardım $(\mathrm{r}=.12, \mathrm{p}<.01)$, yaşl1/ hastalara yardım $(\mathrm{r}=.14$, $\mathrm{p}<.01)$, fiziksel güce dayalı yardım $(\mathrm{r}=.14, \mathrm{p}<.01)$, eğitim sürecinde yardım $(\mathrm{r}=.11, \mathrm{p}<.01)$ arasında pozitif yönde bir ilişki bulunurken travmatik durumlarda yardım ve yakınlık duygusundan kaynaklanan yardım 
ile aralarında herhangi bir ilişki tespit edilememiştir.

\section{Üniversite Öğrencilerinin Mükemmeliyetçi Kendini Gösterme Düzeyleriyle Özgecilik Özelliklerinin Regresyon Analizlerine İlişikin Bulgular}

Bu bölümde sırasıyla özgecilik düzeyinin alt boyutları olan gönüllü faaliyetlere katılım, maddi yardımı, travmatik durumlarda yardım, yaşlı/ hastalara yardım, fiziksel güce dayalı yardım, eğitim sürecinde yardım, yakınlık duygusundan kaynaklanan yardım ile onların yordayıcısı olan mükemmeliyetçi kendini göstermenin alt boyutları olan mükemmeliyetçi öztanıtım, kusur saklamave kusuru açığa vurmama arasındaki ilişkileri ortaya koyan çoklu regresyon analizleri raporlanacaktır.

\section{Gönüllü Faaliyetlere Katılım Düzeyleri Çoklu Regresyon Analiz Sonuçları}

Üniveriste öğrencilerinin gönüllü faaliyetlere katılım özgecilik özelliğini yordayan mükemmeliyetçi kendini gösterme bileşenlerini belirlemek amacıyla çoklu regresyon analizi gerçekleştirilmiştir. Çoklu regresyon sonuçları tablo 7'de gösterilmiştir.

Tablo 7. Üniversite ÖğrencilerininGönülliü Faaliyetlere Katılım Dïzeyleri Regresyon Analiz Sonuçları

\begin{tabular}{lllllllllll}
\hline Model & $\begin{array}{l}\text { Yordayıcı } \\
\text { değişkenler }\end{array}$ & $\mathbf{B}$ & $\begin{array}{l}\text { Std. } \\
\text { Hata }\end{array}$ & $\begin{array}{l}\text { Beta } \\
(\boldsymbol{\beta})\end{array}$ & $\mathbf{T}$ & $\mathbf{P}$ & $\boldsymbol{R}$ & $\boldsymbol{R}^{2}$ & $\Delta \boldsymbol{R} \mathbf{2}$ & $\boldsymbol{F}$ \\
\hline Sabit & 22.2 & 1.29 & & 17.162 & .001 & & & & \\
Öz-Tanıtım & -0.04 & 0.03 & -0.078 & -1.284 & .200 & & & & \\
Kusur saklama & .007 & 0.04 & 0.012 & 0.187 & .852 & 0.15 & 0.02 & 0.02 & $3.615^{*}$ \\
$\begin{array}{l}\text { Kusuru açı̆̆a } \\
\text { vurmama }\end{array}$ & .137 & 0.04 & 0.157 & 3.03 & .003 & & & & \\
\hline
\end{tabular}

${ }^{*} p<.05,{ }^{* *} p<.01,{ }^{* * *} p<.001$

Üniversite öğrencilerinin gönüllü faaliyetlere katılım özgecilik özelliğini yordayan mükemmeliyetçi kendini gösterme bileşenlerini(mükem- 
meliyetçi öz-tanıtım, kusur saklamave kusuru açı̆̆a vurmama) belirlemek amacıyla çokluregresyon analizi gerçekleştirilmiş ve sonuçlar tablo 7'de sunulmuştur.

Buna göre genel modelin anlamlı olduğu görülmektedir ve üniversite öğrencilerinin gönüllü faaliyetlere katılım özgecilik özelliğini sadece mükemmeliyetçi kendini gösterme bileşenlerinden kusuru açı̆̆a vurmamanin yordadı̆̆ tespit edilmiştir $\left(\mathrm{F}=(496,3)=3.615, \mathrm{p}<.05, \mathrm{R}^{2}=.02\right)$.

Kusuru açığa vurmamanın modele katkıları göz önüne alındığında üniversite öğrencilerinin gönüllü faaliyetlere katılım özgecilik özelliğini pozitif yönde yordadiğı söylenebilir $(\beta=.157, \mathrm{t}(496)=3.03 p=0.01)$. Diğer

bağımsız değişkenlerin modele herhangi bir katkılarının olmadığı görülmektedir. Modelde yer alan kusuru açı̆̆a vurmamanın gönüllü faaliyetlere katılım özgecilik özelliğinin \% 2'sini açıklama gücüne sahip olduğu görülmektedir.

\section{Maddi Yardım Düzeyleri Çoklu Regresyon Analiz Sonuçlan}

Üniveriste öğrencilerinin maddi yardım özgecilik özelliğini yordayan mükemmeliyetçi kendini gösterme bileşenlerini belirlemek amacıyla çoklu regresyon analizi gerçekleştirilmiştir. Çoklu regresyon sonuçları Tablo 8 'de gösterilmiştir.

Tablo 8. Üniversite Öğrencilerinin Maddi Yardım Düzeyleri Regresyon Analiz Sonuçları

\begin{tabular}{lllllllllll}
\hline Model & $\begin{array}{l}\text { Yordayıcı } \\
\text { değişkenler }\end{array}$ & $\mathbf{B}$ & $\begin{array}{l}\text { Std. } \\
\text { Hata }\end{array}$ & $\begin{array}{l}\text { Beta } \\
(\boldsymbol{\beta})\end{array}$ & $\mathbf{T}$ & $\mathbf{P}$ & $\boldsymbol{R}$ & $\boldsymbol{R}^{2}$ & \multirow{2}{*}{$\Delta \boldsymbol{R} \mathbf{2}$} & $\boldsymbol{F}$ \\
\hline Sabit & 21.624 & 1.02 & & 21.14 & .001 & & & & \\
Öz-Tanıtım & -0.068 & 0.02 & -0.162 & -2.68 & .007 & 0.177 & 0.031 & 0.026 & $5.36^{* * *}$ \\
Kusur saklama & 0.022 & 0.03 & 0.046 & 0.71 & .473 & & & & \\
Kusuru açı̆ga & 0.115 & 0.03 & 0.166 & 3.22 & .001 & & & & \\
vurmama & 0.115 & & & & & & & & & \\
\hline
\end{tabular}

${ }^{*} p<.05,{ }^{* *} p<.01,{ }^{* * *} p<.001$

Üniversite öğrencilerinin maddi yardım özgecilik özelliğini yordayan mükemmeliyetçi kendini gösterme bileşenlerini(mükemmeliyetçi öz-tanıtım, kusur saklama ve kusuru açığa vurmama) belirlemek amacıyla çoklu regresyon analizi gerçekleştirilmiş ve sonuçlar tablo 8'de sunulmuştur. 
Buna göre genel modelin anlamlı olduğu görülmektedir ve üniversite öğrencilerinin maddi yardım özgecilik özelliğini sadece mükemmeliyetçi kendini gösterme bileşenlerinden kusuru açığa vurmamanın yordadığ1 tespit edilmiştir $\left(\mathrm{F}=(496,3)=5.36, \mathrm{p}<.001, \mathrm{R}^{2}=.03\right)$.

Kusuru açığa vurmamanın modele katkıları göz önüne alındığında üniversite öğrencilerinin maddi yardım özgecilik özelliğini pozitif yönde yordadı ̆̆ 1 söylenebilir $(\beta=.166, \mathrm{t}(496)=3.22 \mathrm{p}=0.001)$. Diğer bağımsız değişkenlerin modele herhangi bir katkılarının olmadığı görülmektedir.

Modelde yer alan kusuru açığa vurmamanın maddi yardım özgecilik özelliğinin \% 3'ünü açıklama gücüne sahip olduğu görülmektedir.

\section{Travmatik Durumlarda Yardım Düzeyleri Çoklu Regresyon Analiz Sonuçları}

Üniveriste öğrencilerinintravmatik durumlarda yardım özgecilik özelliğini yordayan mükemmeliyetçi kendini gösterme bileşenlerini belirlemek amacıyla çoklu regresyon analizi gerçekleştirilmiştir. Çoklu regresyon sonuçları Tablo 9'da gösterilmiştir.

Tablo 9. Üniversite Öğrencilerinin Travmatik Durumlarda Yardım Dïzeyleri Regresyon Analiz Sonuçları

\begin{tabular}{|c|c|c|c|c|c|c|c|c|c|c|}
\hline Model & $\begin{array}{l}\text { Yordayıcı } \\
\text { değişkenler }\end{array}$ & B & $\begin{array}{l}\text { Std. } \\
\text { Hata }\end{array}$ & $\begin{array}{l}\text { Beta } \\
(\beta)\end{array}$ & $\mathbf{t}$ & $\mathbf{P}$ & $R$ & $R^{2}$ & $\Delta R 2$ & $F$ \\
\hline & Sabit & 24.159 & 0.88 & & 27.41 & .001 & \multirow{4}{*}{0.14} & \multirow{4}{*}{0.02} & \multirow{4}{*}{0.02} & \multirow{4}{*}{$3.563^{*}$} \\
\hline & Öz-Tanıtım & -0.059 & 0.02 & -0.164 & -2.70 & .007 & & & & \\
\hline & Kusur saklama & 0.016 & 0.02 & 0.038 & 0.59 & .551 & & & & \\
\hline & $\begin{array}{l}\begin{array}{l}\text { Kusuru açığa } \\
\text { vurmama }\end{array}\end{array}$ & 0.064 & 0.03 & 0.108 & 2.08 & .038 & & & & \\
\hline
\end{tabular}

${ }^{*} p<.05,{ }^{* *} p<.01,{ }^{* * *} p<.001$

Üniversite öğrencilerinin travmatik durumlarda yardım özgecilik özelliğini yordayan mükemmeliyetçi kendini gösterme bileşenlerini (mükemmeliyetçi öz-tanıtım, kusur saklama ve kusuru açığa vurmama) belirlemek amaciyla çoklu regresyon analizi gerçekleştirilmiş ve sonuçlar tablo $9^{\prime}$ da sunulmuştur. 
Buna göre genel modelin anlamlı olduğu görülmektedir ve üniversite öğrencilerinin travmatik durumlarda yardım özgecilik özelliğini mükemmeliyetçi kendini gösterme bileşenlerinden mükemmeliyetçi öz-tanitım ve kusuru açığa vurmamanın anlamlı bir şekilde yordadığı tespit edilmiş$\operatorname{tir}(\mathrm{F}=(496,3)=3.563, \mathrm{p}<.05, \mathrm{R} 2=.02)$.

Değişkenlerin modele tek tek katkıları göz önüne alındığında mükemmeliyetçi öz-tanıtım özelliğinin üniversite öğrencilerinin travmatik durumlarda yardım özgecilik özelliğini negatif yönde yordarken $(\beta=-0.164$, $\mathrm{t}(496)=-2.70 \mathrm{p}=0.01)$, diğer yandan kusuru açığa vurmama ise üniversite öğrencilerinin travmatik durumlarda yardım özgecilik özelliğini pozitif yönde yordadığı görülmektedir $(\beta=.108, t(496)=2.08 p=0.05)$. Diğer bağımsız değişken olankusur saklama modele herhangi bir katkısı olmadığ 1 görülmektedir. Modelde yer alan öz-tanıtım kusuru açı̆̆a vurmamatravmatik durumlarda yardımözgecilik özelliğinin \% 2'sini açılama gücüne sahip olduğu görülmektedir.

\section{Yaşlı/Hastalara Yardım Düzeyleri Çoklu Regresyon Analiz Sonuçlan}

Üniveriste öğrencilerininyaşlı/ hastalara yardım özgecilik özelliğini yordayan mükemmeliyetçi kendini gösterme bileşenlerini belirlemek amacıyla çoklu regresyon analizi gerçekleştirilmiştir. Çoklu regresyon sonuçları Tablo 10'da gösterilmiştir.

Tablo 10. Üniversite Öğrencilerinin Yaşlı/Hastalara Yardım Düzeyleri Regresyon Analiz Sonuçları

\begin{tabular}{|c|c|c|c|c|c|c|c|c|c|c|}
\hline Model & $\begin{array}{l}\text { Yordayıcı } \\
\text { değişkenler }\end{array}$ & B & $\begin{array}{l}\text { Std. } \\
\text { Hata }\end{array}$ & $\begin{array}{l}\text { Beta } \\
(\beta)\end{array}$ & $\mathbf{t}$ & $\mathbf{P}$ & $R$ & $R^{2}$ & $\Delta R 2$ & $F$ \\
\hline & Sabit & 14.567 & 0.70 & & 20.78 & .001 & \multirow{4}{*}{0.19} & \multirow{4}{*}{0.04} & \multirow{4}{*}{0.03} & \multirow{4}{*}{$6.20^{* * *}$} \\
\hline & Öz-Tanıtım & -0.034 & 0.01 & -0.117 & -1.95 & .052 & & & & \\
\hline & Kusur saklama & -0.013 & 0.02 & -0.039 & -0.61 & .542 & & & & \\
\hline & $\begin{array}{l}\text { Kusuru } \\
\text { açı̆ga vurmama }\end{array}$ & 0.099 & 0.02 & 0.207 & 4.03 & .001 & & & & \\
\hline
\end{tabular}

${ }^{*} p<.05,{ }^{* *} p<.01,{ }^{* * *} p<.001$

Üniversite öğrencilerinin yaşlı/ hastalara yardımözgecilik özelliğini yordayan mükemmeliyetçi kendini gösterme bileşenlerini (mükemmeliyetçi öz-tanıtım, kusur saklamave kusuru açı̆ga vurmama) belirlemek 
amacıyla çoklu regresyon analizi gerçekleştirilmiş ve sonuçlar tablo 10'da sunulmuştur.

Buna göre genel modelin anlamlı olduğu görülmektedir ve üniversite öğrencilerinin yaşlı/ hastalara yardımözgecilik özelliğini sadece mükemmeliyetçi kendini gösterme bileşenlerinden kusuru açığa vurmamanın yordadığ1 tespit edilmiştir $\left(\mathrm{F}=(496,3)=6.20, \mathrm{p}<.001, \mathrm{R}^{2}=.04\right)$.

Kusuru açığa vurmamanın modele katkıları göz önüne alındığında üniversite öğrencilerinin yaşlı/ hastalara yardımözgecilik özelliğini pozitif yönde yordadığı söylenebilir $(\beta=.207, \mathrm{t}(496)=4.03 p=0.001)$. Diğer bağımsız değişkenlerin modele herhangi bir katkılarının olmadığı görülmektedir. Modelde yer alan kusuru açığa vurmamanın yaşlı/ hastalara yardım özgecilik özelliğinin \% 4'ünü açıklama gücüne sahip olduğu görülmektedir.

\section{Fiziksel Güce Dayalı Yardım Düzeyleri Çoklu Regresyon Analiz Sonuçları}

Üniversite öğrencilerinin fiziksel güce dayalı yardım özgecilik özelliğini yordayan mükemmeliyetçi kendini gösterme bileşenlerini belirlemek amacıyla çoklu regresyon analizi gerçekleştirilmiştir. Çoklu regresyon sonuçları Tablo 11'de gösterilmiştir.

Tablo 11. Üniversite Öğrencilerinin Fiziksel Güce Dayalı Yardım Düzeyleri Regresyon Sonuçları

\begin{tabular}{|c|c|c|c|c|c|c|c|c|c|c|}
\hline $\begin{array}{l}\text { Mo- } \\
\text { del }\end{array}$ & $\begin{array}{l}\text { Yordayıcı } \\
\text { değişkenler }\end{array}$ & B & $\begin{array}{l}\text { Std. } \\
\text { Hata }\end{array}$ & $\begin{array}{l}\text { Beta } \\
(\beta)\end{array}$ & $\mathrm{T}$ & p & $R$ & $R^{2}$ & $\Delta R 2$ & $F$ \\
\hline & Sabit & 16.699 & 0.88 & & 18.84 & .001 & \multirow{4}{*}{0.19} & \multirow{4}{*}{0.04} & \multirow{4}{*}{0.03} & \multirow{4}{*}{$6.01^{* * *}$} \\
\hline & Öz-Tanıtım & -0.062 & 0.02 & -0.170 & -2.83 & .005 & & & & \\
\hline & Kusur saklama & 0.046 & 0.02 & 0.108 & 1.70 & .090 & & & & \\
\hline & $\begin{array}{l}\text { Kusuru } \\
\text { açığa vurmama }\end{array}$ & 0.093 & 0.03 & 0.155 & 3.02 & .003 & & & & \\
\hline
\end{tabular}

${ }^{*} p<.05, * * p<.01, * * * p<.001$

Üniversite öğrencilerinin fiziksel güce dayalı yardım özgecilik özelliğini yordayan mükemmeliyetçi kendini gösterme bileşenlerini (mükem- 
meliyetçi öz-tanıtım, kusur saklama ve kusuru açığa vurmama) belirlemek amaciyla çoklu regresyon analizi gerçekleştirilmiş ve sonuçlar Tablo 11 'de sunulmuştur.

Buna göre genel modelin anlamlı olduğu görülmektedir ve üniversite öğrencilerinin fiziksel güce dayalı yardım özgecilik özelliğini mükemmeliyetçi kendini gösterme bileşenlerinden mükemmeliyetçi öz-tanıtım ve kusuru açığa vurmamanın anlamlı bir şekilde yordadığı tespit edilmiştir $(\mathrm{F}=(496,3)=6.01, \mathrm{p}<.001, \mathrm{R} 2=.04)$.

Değişkenlerin modele tek tek katkıları göz önüne alındığında mükemmeliyetçi öz-tanıtım özelliğinin üniversite öğrencilerinin fiziksel güce dayalı yardım özgecilik özelliğini negatif yönde yordarken $(\beta=-0.170, t$ (496) =-2.83 p=0.01), diğer yandan kusuru açığa vurmama ise üniversite öğrencilerinin fiziksel güce dayalı yardımözgecilik özelliğini pozitif yönde yordadığı görülmektedir $(\beta=0.155, \mathrm{t}(496)=3.02 \mathrm{p}=0.01)$. Diğer bağımsız değişken olan kusur saklamanın modele herhangi bir katkısı olmadığı görülmektedir. Modelde yer alan mükemmeliyetçi öz-tanıtım ve kusuru açığa vurmama fiziksel güce dayalı yardım özgecilik özelliğinin \% 3'ünü açılama gücüne sahip olduğu görülmektedir.

\section{Eğitim Sürecinde Yardım Düzeyleri Çoklu Regresyon Analiz Sonuç- ları}

Üniveriste öğrencilerinineğitim sürecinde yardım özgecilik özelliğini yordayan mükemmeliyetçi kendini gösterme bileşenlerini belirlemek amacıyla çoklu regresyon analizi gerçekleştirilmiştir. Çoklu regresyon sonuçları Tablo 12'de gösterilmiştir.

Tablo 12. Üniversite Öğrencilerinin Eğitim Sürecinde Yardım Düzeyleri Regresyon Analiz Sonuçları

\begin{tabular}{|c|c|c|c|c|c|c|c|c|c|c|}
\hline Model & $\begin{array}{l}\text { Yordayıcı } \\
\text { değişkenler }\end{array}$ & B & $\begin{array}{l}\text { Std. } \\
\text { Hata }\end{array}$ & $\begin{array}{l}\text { Beta } \\
(\beta)\end{array}$ & $\mathbf{t}$ & p & $R$ & $R^{2}$ & $\Delta R 2$ & $F$ \\
\hline & Sabit & 17.767 & 0.73 & & 24.10 & .001 & \multirow{4}{*}{0.14} & \multirow{4}{*}{0.02} & \multirow{4}{*}{0.02} & \multirow{4}{*}{$3.49^{*}$} \\
\hline & Öz-Tanitım & -0.037 & 0.01 & -0.121 & -1.99 & .046 & & & & \\
\hline & Kusur saklama & 0.027 & 0.02 & 0.078 & 1.21 & .225 & & & & \\
\hline & $\begin{array}{l}\text { Kusuru } \\
\text { açı̆ga vurmama }\end{array}$ & 0.062 & 0.02 & 0.124 & 2.39 & .017 & & & & \\
\hline
\end{tabular}

${ }^{*} p<.05,{ }^{* *} p<.01,{ }^{* * *} p<.001$ 
Üniversite öğrencilerinin eğitim sürecinde yardım özgecilik özelliğini yordayan mükemmeliyetçi kendini gösterme bileşenlerini (mükemmeliyetçi öz-tanıtım, kusur saklamave kusuru açığa vurmama) belirlemek amacıyla çoklu regresyon analizi gerçekleştirilmiş ve sonuçlar Tablo 12' de sunulmuştur.

Buna göre genel modelin anlamlı olduğu görülmektedir ve üniversite öğrencilerinin eğitim sürecinde yardım özgecilik özelliğini mükemmeliyetçi kendini gösterme bileşenlerinden mükemmeliyetçi öz-tanıtım ve kusuru açığa vurmamanın anlamlı bir şekilde yordadığ $\left(\mathrm{F}=(496,3)=3.49, \mathrm{p}<.05, \mathrm{R}^{2}=.02\right)$.

Değişkenlerin modele tek tek katkıları göz önüne alındığında mükemmeliyetçi öz-tanıtım özelliğinin üniversite öğrencilerinin eğitim sürecinde yardım özgecilik özelliğini negatif yönde yordarken $(\beta=-0.121, \mathrm{t}$ $(496)=-1.99 \mathrm{p}=0.05)$, diğer yandan kusuru açı̆̆a vurmama ise üniversite öğrencilerinin eğitim sürecinde yardım özgecilik özelliğini pozitif yönde yordadı ğ görülmektedir $(\beta=.124, \mathrm{t}(496)=2.39 \mathrm{p}=0.05)$.

Diğer bağımsız değişken olan kusur saklamanın modele herhangi bir katkısı olmadığı görülmektedir. Modelde yer alan mükemmeliyetçi öz-tanıtım ve kusuru açığa vurmama eğitim sürecinde yardım özgecilik özelliğinin \% 2'sini açklama gücüne sahip olduğu görülmektedir.

\section{Yakınlı Duygusundan Kaynaklanan Yardım Düzeyleri Çoklu Regresyon Analiz Sonuçlarn}

Üniveriste öğrencilerinin yakınlık duygusundan kaynaklanan yardım özgecilik özelliğini yordayan mükemmeliyetçi kendini gösterme bileşenlerini belirlemek amacıyla çoklu regresyon analizi gerçekleştirilmiştir. Çoklu regresyon sonuçları Tablo 20' de gösterilmiştir.

Üniversite öğrencilerinin yakınlık duygusundan kaynaklanan yardım özgecilik özelliğini yordayan mükemmeliyetçi kendini gösterme bileşenlerini (mükemmeliyetçi öz-tanıtım, kusur saklama ve kusuru açığa vurmama) belirlemek amacıyla çoklu regresyon analizi gerçekleştirilmiş ve sonuçlar Tablo 13'te sunulmuştur. Buna göre genel modelin anlamlı olduğugörülmektedir ve üniversite öğrencilerinin yakınlık duygusundan kaynaklanan yardım özgecilik özelliğini mükemmeliyetçi kendini gösterme 
bileşenlerinden mükemmeliyetçi öz-tanıtım ve kusur saklamanın anlamlı bir şekilde yordadığ tespit edilmiştir $\left(\mathrm{F}=(496,3)=7.57, \mathrm{p}<.001, \mathrm{R}^{2}=.04\right)$.

Tablo 13. Üniversite Öğrencilerinin Yakınlık Duygusundan Kaynaklanan Yardım Düzeyleri Regresyon Analiz Sonuçlarn

\begin{tabular}{|c|c|c|c|c|c|c|c|c|c|c|}
\hline $\begin{array}{l}\text { Mo- } \\
\text { del }\end{array}$ & $\begin{array}{l}\text { Yordayıcı } \\
\text { değişkenler }\end{array}$ & B & $\begin{array}{l}\text { Std. } \\
\text { Hata }\end{array}$ & Beta $(\beta)$ & $\mathbf{t}$ & $\mathbf{P}$ & $R$ & $R^{2}$ & $\Delta R 2$ & $F$ \\
\hline & Sabit & 17.168 & 0.80 & & 21.39 & .001 & \multirow{4}{*}{0.21} & \multirow{4}{*}{0.04} & \multirow{4}{*}{0.04} & \multirow{4}{*}{$7.57^{* * *}$} \\
\hline & Öz-Tanıtım & -0.040 & 0.02 & -0.119 & -1.98 & .048 & & & & \\
\hline & Kusur saklama & 0.105 & 0.02 & 0.271 & 4.28 & .001 & & & & \\
\hline & $\begin{array}{l}\text { Kusuru açığa } \\
\text { vurmama }\end{array}$ & -5.115 & 0.02 & -9.353 & -0.09 & .985 & & & & \\
\hline
\end{tabular}

${ }^{*} p<.05,{ }^{* *} p<.01,{ }^{* * *} p<.001$

Değişkenlerin modele tek tek katkıları göz önüne alındığında mükemmeliyetçi öz-tanıtım özelliğinin üniversite öğrencilerinin yakınlık duygusundan kaynaklanan yardım özgecilik özelliğini negatif yönde yordarken $(\beta=-0.119, \mathrm{t}(496)=-1.98 \mathrm{p}=0.05)$, diğer yandan kusur saklama ise üniversite ögrencilerinin yakınlık duygusundan kaynaklanan yardım özgecilik özelliğini pozitif yönde yordadığ1 görülmektedir ( $\beta=.271$, t (496 ) $=4.28$ p= 0.001). Diğer bağımsız değişken olan kusuru açığa vurmamanın modele herhangi bir katkısı olmadığı görülmektedir. Modelde yer alan mükemmeliyetçi öz-tanıtım ve kusur saklama yakınlık duygusundan kaynaklanan yardım özgecilik özelliğinin \% 4'ünü açıklama gücüne sahip olduğu görülmektedir.

\section{Tartışma, Sonuç ve öneriler}

$\mathrm{Bu}$ araştırmanın temel amacı, üniversite öğrencilerinde özgecilik düzeyleri ile mükemmeliyetçilik özellikleri arasındaki ilişkinin incelenmesi olarak belirlenmiştir. Aynı zamanda üniversite öğrencilerinin özgecilik düzeyleri ve mükemmeliyetçilik özelliklerinin cinsiyet, yaş değişkenleri açısından farklılaşıp farklılaşmadığını amaç edinmiştir.

$\mathrm{Bu}$ araştırma sonuçlarına göre, üniversite öğrencilerinin özgecilik düzeyleri incelendiğinde, cinsiyete göre kadınlar ve erkekler arasında anlamlı bir farklılık olduğu görülmektedir. Buna göre kadınların da 
özgecilik davranışı erkeklere göre daha yüksek olduğu söylenebilir. Elde edilen sonucun etki büyüklüğünün orta düzeyde anlamlı olduğu tespit edilmiştir.

Elmas (1998) tarafından yapılan araştırmada da, kadınların erkeklerden daha özgeci olduğu sonucuna varılmıştır. Avcı, Aydın, Özbaşan (2013) tarafından yapılmış çalışmada kız öğrencilerin özgecilik puan ortalamalarının erkek öğrencilerden daha yüksek olduğu ortaya çıkmakla birlikte, aralarında istatistiksel olarak anlamlı bir fark saptanmamıştır.

Akbaba (1994) özgecilik söz konusu olduğunda cinsiyetin belirleyici bir değişken olmadığı sonucuna ulaşmıştır. Mutafçılar (2008) tarafından yapılan araştırmanın sonuçlarına göre, ögretmenlerin cinsiyetleri ile özgecilik düzeyleri arasında anlamlı bir fark bulunamamıstır. Kasapoğlu(2013) tarafından yapılan bir araştırmaya göre, özgeciliğin cinsiyete göre değişmediği görülmüştür. Koçak, Ak (2015) tarafından yapılan bir araştırmaya göre, öğrencilerin özgecilik puan ortalamaları incelendiğinde, kız öğrencilerin ortalaması ile erkek öğrencilerin puan ortalamasının birbirlerine yakın olduğu ortaya çıkmış ve cinsiyet değişkenine göre öğrencilerin özgecilik puanları arasında anlamlı bir fark olmadığ1 sonucuna ulaşılmıştır. Andreoni ve Vesterlund (2001) tarafından yapılan araştırmada kadınların erkeklerden daha empatik, özverili ve cömert olduğu ortaya çıkmıştır.

Araştırmanın değişkenlerinden biri olan cinsiyet ile özgecilik düzeyleri arasında anlamlı bir farklılık bulunduğu görülmüştür. Ancak görüldüğü gibi, alanyazında cinsiyet değişkeni ile özgecilik arasındaki ilişkiyi inceleyen araştırmalarda birbirinden farklı sonuçlar tespit edilmiştir. Araştırma sonuçları bu farkın çok büyük olmadığını da ortaya koymaktadır. Bu bulgular ışığında, annelik içgüdüsüne sahip olmanın kadınların daha empatik, özgeci ve şefkatli tepkiler vermesine neden olduğu düşünülmektedir.

$\mathrm{Bu}$ araştırmaya katılan üniversite öğrencilerinde 18-20 yaş özgecilik puanı ortalaması ile 21-23 yaş arası öğrencilerin puanı ortalaması ve 27 ve üstü öğrencilerin puan ortalaması arasındaki fark anlamlı bulunmuştur. Araştırma sonuçlarından elde edilen bulgulara göre, 21-23 yaşları arasında bulunan üniversite öğrencilerinde özgecilik davranışı 1820 yaş arasından daha yüksektir. Benzer şekilde 27 yaş ve üstü 
öğrencilerde özgecilik davranışı 18-20 yaş arasındakilerden daha yüksektir. Kasapoğlu (2013) tarafından yapılan araştırmanın sonuçlarına göre, 3. sınıf öğrencilerinin özgecilik düzeyinin 1. sınıf öğrencilerine göre daha yüksek olduğu saptanmıştır. Yeşilkayalı (2015) tarafından yapılan bir araştırmanın sonuçlarına göre, koruyucu aile bireylerinin yaş grubu ile toplam özgecilik düzeyi ortalamalarında istatistiksel olarak anlamlı bir farklılık saptanmamıştır. Ancak, en yüksek özgecilik düzeyinin ortalaması 58 ve üstü yaşlarda, en düşük ortalamanın ise 47-57 yaş grubunda olduğu tespit edilmiştir. Van Slyke ve Brooks (2005) tarafından yapılan bir çalışmada, yaş arttıkça kar amacı gütmeyen kuruluşlar için gönüllü çalışmalara ve hayır faaliyetlerine katılmanın arttığı ve yaş düzeyinin kişinin hayırseverlik düzeyini de olumlu şekilde etkilediği tespit edilmiştir. Bu bulgular ışığında yaş arttıkça aslında özgeciliğin değişmesi değil de, yardımseverliğin arttığı düşünülmektedir. Yetişkinliğe doğru özgeci davranışların artması, kişinin tek kendi için değil, etrafı için de sorumluluk duyması, kendi değerini fark etmesi ve başkalarının da en az kendisi kadar değerli olduğunu düşünmesi şeklinde yorumlanabilir. Aynı zamanda yetişkinlik dönemi ile birlikte evlilik, çocuk sahibi olmak gibi rol geçişlerinin de kişinin daha empatik bakış açısı geliştirmesine neden olduğu düşünülmektedir.

Yapılan araştırmada üniversite öğrencilerinde özgecilik davranışı ve mükemmeliyetçilik arasında anlamlı ilişikilerin olduğu tespit edilmiştir.

Stoeber (2015) tarafından yapılan bir araştırmanın sonucuna göre, başkaları yönelimli mükemmeliyetçilik özgecilik ile benzersiz bir negatif ilişki göstermiştir. Bu, başkalarına yönelik mükemmeliyetçilerin diğer insanlara göre daha az duygusal, kabul edici ve şefkatli olduklarını düşündürecek bir sonuçtur. Kendi yönelimli mükemmeliyetçilik ise, kendine yönelik mükemmeliyetçilerin, ihtiyacı olanlara karşı diğer insanlardan daha şefkatli olduğunu düşündürecek şekilde özgecilikle benzersiz pozitif ilişkiler göstermiş̧ir.Vyunova, Larskikh, Strebkova (2014) tarafından yapılan bir araştırmanın sonuçlarına göre, yapıcı mükemmeliyetçilik ve tutku kendi içinde özgecil özellikleri barındırmaktadır. Yapıcı mükemmeliyetçinin özgeciliği doğrudan ya da dolaylı olarak kendi menfaat ve beklentisi için çalışan kişiye yarar sağlamaktadır. Yapılan diğer çalışmalar da özgecilik ve 
mükemmeliyetçilik arasında anlamlı ilişkilerin olduğunu destekler niteliktedir.

$\mathrm{Bu}$ araştırmanın sonuçlarına göre, mükemmeliyetçi öz-tanıtım özelliği üniversite öğrencilerinin travmatik durumlarda yardım özgecilik özelliği, fiziksel güce dayalı yardım özgecilik özelliği, eğitim sürecinde yardım özgecilik özelliği ve yakınlık duygusundan kaynaklanan yardım özgecilik özelliği ile negatif yönde ilişikili olduğu tespit edilmiştir. Bu sonuçlara göre, mükemmeliyetçi öz-tanıtım özelliğine sahip bireylerin özgecilik düzeylerinin düşük olduğu düşünülmektedir. Kişinin sürekli olumlu yönlerini, becerilerini ve yaptığı işleri ön plana çıkarması, kendini mükemmel bir insan olarak göstermeye çalışması durumu ile özgecilik arasında negatif ilişkilerin ortaya çıkması beklenen bir sonuçtur. Özgeciliğin tamamen kendi çıkarını gözetmeksizin gerçekleştirilen bir davranış olduğu düşünülmemektedir. Özgecilik kişinin başkaları tarafından beğenilme, onaylanma ihtiyacının sonucu olarak da ortaya çıkabilir. Bunun yanısıra, sadece kendini ön plana çıkaran, kendini mükemmel insan olarak göstermeye çalışan kişinin de özgeci olamayacağ1 düşünülmektedir.

$\mathrm{Bu}$ araştırmanın sonuçlarına göre, üniversite öğrencilerinin yakınlık duygusundan kaynaklanan yardım özgecilik özelliğinin mükemmeliyetçi kendini gösterme kusur saklama özelliği ile pozitif ilişkili olduğu ortaya çıkmıştır. Taylor, Peplau, Sears (2015) tarafından belirtildiği gibi, insanların yakın akraba ve arkadaşlarına yabancılardan daha fazla yardım etmesi yakın olanlar için daha fazla sorumluluk duyma ve gerektiğinde onlardan da yardım alma ile bağlantılıdır. Esin (2016) tarafından belirtildiği gibi, normalde içgüdüsel olan yardımlaşma isteği, özgecilikte ise insanın kişiler ya da gruplar tarafından beğenilme, onaylanma ve beklediği yakınlık isteğinin sonucu olarak kendini göstermektedir. Karşılıklılığın özgeciliğin bir normu olduğu belirtilerek, gerektiğinde başkalarından yardım isteme fikrinin kusur saklamaya neden olabileceği düşünülmektedir. Diğer taraftan yanlışları ya da eksiklikleri ile özellikle de yakın çevresi tarafından kabul edilememekten korkan kişinin kaçış olarak özgeciliği seçtiği de düşünülmektedir.

$\mathrm{Bu}$ araştırma sonuçlarına göre, üniversite öğrencilerinde gönüllü faaliyetlere katılım özgecilik özelliğine sahip kişilerin mükemmeliyetçi kendini gösterme kusuru açığa vurmama özelliğinin yüksek olduğu 
söylenebilir. Benzer şekilde üniversite öğrencilerinde maddi yardım özgecilik özelliğine sahip üniversite öğrencilerinin kusuru açı̆̆a vurmama özelliğinin de yüksek olduğu görülmüştür. Yine benzer şekilde travmatik durumlarda yardım özgecilik özelliği, yaşlı/ hastalara yardım özgecilik özelliği, fiziksel güce dayalı yardım özgecilik özelliği ve eğitim sürecinde yardım özgecilik özelliği ile kusuru açığa vurmama özelliğinin pozitif ilişkili olduğu tespit edilmiştir. Wedekind ve Braitwaite (2002) tarafından yapılan bir araştırmaya göre, karşılıklı özgecilik kavramının önemli bir bileşeni de insanların özgeci ve güvenilir olarak ün kazanmasıdır. Ariely, Brancha ve Meiser (2009) tarafından yapılmış araştırmada, öğrenciler, en az bağışı, para kazandıkları ve kimsenin sonucu görmediği durumlarda yapıyor. En çok bağışı ise herkesin gördüğü durumlarda yapıyor. Öğrenciler, herkesin gördüğü durumda çıkarcı algılanmamak için daha çok bağış yapmıştır. Kusuru açığa vurmama özelliği ile özgecilik arasında pozitif ilişkilerin ortaya çıkması sonucuna göre onay alma ihtiyacının özgeci davranışlara neden olduğu düşünülmektedir.

Cinsiyet bağlamında özgecilik davranışlarını incelediğimizde kadınların erkeklerden daha fazla özgeci davranış içinde bulundukları tespit edilmiştir. Yaşı küçük olan üniversite öğrencilerinin büyük olanlara göre daha az özgeci davranış gösterdikleri tespit edilmiştir.

Üniversite öğrencilerinde özgecilik davranışı ve mükemmeliyetçi kendini gösterme arasında anlamlı ilişikilerin olduğu tespit edilmiştir.

Gönüllü faaliyetlere katılım, maddi yardım özgecilik özelliğine sahip üniversite öğrencilerinde mükemmeliyetçi kendini gösterme kusuru açığa vurmama özelliğinin yüksek olduğu tespit edilmiştir.

Travmatik durumlarda yardım, yaşlı/ hastalara yardım, fiziksel güce dayalı yardım, eğitim sürecinde yardım özgecilik özelliğinin mükemmeliyetçi kendini gösterme kusuru açığa vurmama özelliği ile pozitif ilişkili olduğu tespit edilmiştir.

Travmatik durumlarda yardım, fiziksel güce dayalı yardım, eğitim sürecinde yardım özgecilik özelliğinin ise üniversite öğrencilerinin mükemmeliyetçi kendini gösterme öz-tanıtım özelliği ile negatif yönde ilişkili olduğu tespit edilmiştir.

Yakınlık duygusundan kaynaklanan yardım özgecilik özelliğinin ise üniversite öğrencilerinin mükemmeliyetçi kendini gösterme öz-tanitım 
özelliği ile negatif yönde ilişkili olduğu tespit edilmiştir. Buna göre, mükemmeliyetçi kendini gösterme öz-tanıtım özelliğine sahip bireylerin özgecilik düzeylerinin düşük olduğu düşünülmektedir.

Yakınlık duygusundan kaynaklanan yardım özgecilik özelliğinin üniversite öğrencilerinin mükemmeliyetçi kendini gösterme kusur saklama özelliği ile pozitif ilişkili olduğu tespit edilmiştir.

Yardım etme davranışına herhangi bir dış motivasyon eklenmediği zaman insan doğası itibarile özgecidir fikrini ileri süren çalışmaları ( Fabes, 1989., Warneken, Tomasello, 2008) temel alarak Türkiyede de özgecilik-ödül ya da özgecilik- iç/dış motivasyon ilişkisini araştıran çalışmaların yapılabileceği düşünülmektedir.

Özgeci davranışta bulunmak kişiye iyi bir şeyler yapmış olmaktan dolayı olumlu hisler yaşatsa da, özgeciliğin kendini feda halini almış patolojik boyutlarını araştırmak için yeni çalışmaların yapılabileceği ve bu konuda yeni ölçeklerin geliştirilebileceği düşünülmektedir.

Özgeci bireyden beklenen şey davranışlarını dış çevreden bağımsız bir şekilde gerçekleştirebilmesi olsa da, yapılan çalışmada kusuru açığa vurmama ve kusur saklama ile özgecilik arasında pozitif ilişkiler ortaya çıkmıştır. Bu sonuca göre, bireyi özgeci davranışa iten motivasyonla ilgili yeni çalışmaların yapılabileceği düşünülmektedir. 


\title{
EXTENDED ABSTRACT
}

\section{Reviewing of The Relationship Between Altruism And Perfectionism Mentality Among University Students}

\author{
* \\ Kamala Khalınbaylı - Besra Taş \\ İstanbul Gelişim University, İstanbul Sabahattin Zaim University
}

In this research, it is aimed to review the relationship between altruism and perfectionism mentality among university students. The research has been conducted among 250 girls, 250 boys, in total 500 university students who have studied in different public and private universities in İstanbul. The data related to the attendant's altruism levels are obtained by using Altruism Scale, their perfectionism levels were determined by using the Perfectionistic Self-Presentation Scale and data related to personal characteristics was obtained by using Personal Information Form that was issued by the researcher. In regression analysis, points, that are taken from the sub-dimension of the altruism levels among the university students are obtained as dependent variable (attendance to voluntary activities, financial supports, help in the traumatic situations, help for old patient people, help based on physical force, help during the education period, help arisen from feeling closeness), points that are taken from the sub-dimension (perfectionist self-presentation, nondisplay of imperfection and nondisclosure of imperfection) of the perfectionistic self-presentation are obtained as a predictor variable. One way variance analysis and T-test analyses were made to review altruism mentality among the university students whether it becomes different or not according to gender, age, the average income of the family, people of which living together with, family-style that she/he has grown up. According to the research results, it has been determined that there are significant relationships between an altruism act and perfectionism among university students. Also, it has been determined that a woman has been acting more altruist than a man, juniority university students have been acting less altruist than the older ones. 
The effect size of the result obtained has been found to be moderately significant. A significant difference between gender which is one of the variables of the study and altruism levels was found to be present. However, in the literature, different results were found in the studies investigating the relationship between gender variable and altruism. The results of the research show that this difference is not very big. In the light of these findings, it is thought that having maternal instinct causes women to be more empathic, altruistic and compassionate.

According to the results of this study, the perfectionist self-presentation trait was found to be negatively associated with help in the traumatic situations, help based on physical force, help during the education period, help arisen from feeling closeness. According to these results, the altruism level of individuals with perfectionist self-presentation is thought to be low. It is an expected result that negative relations between altruism and the state in which the person constantly emphasizes his positive aspects, skills, and works and tries to show himself as a perfect person. It is thought that altruism is a behavior that is carried out completely without self-interest. Altruism may also arise as a consequence of a person's need for favor and approval by others. In addition, it is believed that the person who makes an effort to stand out and tries to present himself as the perfect person cannot be altruistic.

In accordance with the research results, positive relationships have been found between altruistic trait called help arisen from feeling closeness and trait called nondisclosure of imperfection in perfectionistic self-promotion, among university students. On the other hand, it is also believed that the person who is afraid of inadmissibility by his / her close environment, due to his/her mistakes or deficiencies, chooses altruism as a way out.

According to the results of this research, it can be said that university students attending voluntary activities have a high nondisclosure of imperfection trait. It has been also seen that nondisclosure of imperfection is high among university students with financial support altruism trait. Similarly, nondisclosure of imperfection has been found to be positively related to altruistic financial supports, help in the traumatic situations, help for old patient people, help based on physical force, help during the education period. 
When any external motivation is not added to helping behavior, in Turkey, studies investigating relationship between altruism-reward or altruism- intrinsic and extrinsic motivation can be conducted by referring studies (Fabes, 1989., Warneken, Tomasello, 2008) which support the idea of human is naturally altruistic.

Although altruistic behavior gives the person positive feelings for having done something good, it is thought that new studies can be conducted and new scales can be developed to investigate the selfsacrificing pathological dimensions of altruism.

Although what is expected from the altruistic individual is to be able to behave independently from the external environment, the study revealed positive relationships between altruism and nondisplay imperfection as well as nondisclosure of imperfection. According to this result, it is thought that new studies can be done about the motivation that pushes the individual to altruistic behavior.

\section{Kaynakça / References}

Akbaba, S. (1994). Grupla psikolojik danışmanın sosyal psikolojik bir kavram olarak özgecilik üzerindeki etkisi. Doktora Tezi. Atatürk Üniversitesi, Erzurum.

Akbulut, Y. (2010). Sosyal bilimlerde SPSS uygulamalarl: Sik kullanılan istatiksel analizler ve açıklamalı SPSS çözümleri. İdeal Kültür Yayıncılık.

Antony, M. M. ve Swinson, R.P. (2000). When Perfect isn't Good Enough: Strategies for coping with Perfectionism. Oakland, CA: New Harbinger Publications.

Andreoni, J. ve Vesterlund, L. (2001). Which is the fair sex? Gender differences in altruism. Quartely Journal of Economics, 116(1), 293-312.

Ariely, D., Bracha, A. ve Meiser, S. (2009). Doing good or doing well? Image motivation and monetary incestives in behaving prosocially. American Economic Review, 99 (1), 544-55.

Aronson, E., Wilson, T.D. ve Akert, R. M. (2012). Sosyal psikoloji. (Çev. O. Gündüz). 1. Baskı.İstanbul: Kaknüs Yayınları.

Avcı, D., Aydın, D., Özbaşaran, F. (2013). Hemşirelik öğrencilerinde empatiöğrencilik ilişkisi ve özgeci davranışın bazı değişkenler açısından incelenmesi. Balıkesir Să̆lık Bilimleri Dergisi, 2(2), 108-113. 
Balc1, A., Kıral, E., Kalafat, T. ve Boysan, M. (2009). Kendini mükemmeliyetçi gösterme ölçeğinin türk örnekleminde psikometrik özellikleri. Kriz Dergisi, 17(3), 23-32.

Bolat, Ö. (2018). Beni ödülle cezalandırma. (115. Bs). İstanbul: Doğan Kitap.

Cohen, J. (1988). Statistical power analysis for the behavioral sciences.2nd.

Elmas, U. (1998). Bireylerin anne baba tutumlarn ile özgecilik düzeyleri arasındaki ilişkiler.Yüksek Lisans Tezi. Atatürk Üniversitesi, Erzurum.

Esin, C. (2016). Sol gözüm ne diyor doktor bey? E-book. İstanbul, Turkey.

Ермилова, М. В. (2015). Деловой перфекционизм в современном обществе. Известия Санкт-Петербургского Государственного Аграрного Университета, 71-74.

Fabes, R. A., Fultz, J., Eisenberg, N., May-Plumlee, T. ve Christopher, F. S. (1989). Effects of Rewards on Children's Prosocial Motivation: A Socialization Study. Developmental Psychology, 25, 509-515.

George, D., Mallery, P. (2016). IBM SPSS Statistics 23 step by step: A simple guide and reference. Routledge.

Gerrig, R. J. ve Zimbardo, P. G. (2012). Psikolojiye giriş psikoloji ve yaşam. (Çev. G. Sart), İstanbul: Nobel Akademik Yayıncilik.

Karasar, N. (2011). Bilimsel araştırma yöntemi. Ankara: Nobel Akademik Yayıncilik.

Kasapoğlu, F. ( 2013). Üniversite öğrencilerinde iyilik hali ile özgecilik arasındaki ilişkinin incelenmesi. Yüksek Lisans Tezi. İnönü Üniversitesi. Malatya.

Koçak, R. ve Ak, K. (2015). Üniversite öğrencilerinin özgecilik düzeylerinin yordayıcısı olarak yaşam amaçları. İnternational Journal of Social Science, 38, 1-18.

Lee, K. ve Ashton, M, C. (2004). Psychometric properties of the HEXACO personality inventory. Multivariate Behavioral Research, 39 (2), 329-358.

Mutafçlar, I. (2008). Özgecilik kavramının tarihsel gelişimi ve öğretmen özgeciliği üzerinde bir araştırma. Yüksek Lisans Tezi. Yeditepe Üniversitesi, İstanbul.

Özgüngör, S. (2003). Mükemmeliyetçilik ve özerklik destekleyici davranışların amaç tarzları ile ilişkisi. Ĕğitim ve Bilim, 28(127), 25-30.

Palaz, S. ve Boz, İ. (2008). Üniversite mezunu yetişkinlerin farklı organizasyonlarda gönüllü hizmet vermesini etkileyen faktörler.Balıkesir Üniversitesi Sosyal Bilimler Enstitüsü Dergisi, 11(19), 95-106. 
Stoeber, J. (2015). How other-oriented perfectionism differs from self-oriented and Socially prescribed perfectionism: Further findings. Journal of Psychopathology and Behavioral Assessment, 37 (4), 611-623.

Tabachnick, B. G. ve Fidell, L. S. (2013). Using multivariate statistics. Allyn \& Bacon/ Pearson Education.

Taylor, H. E., Peplau, L. A. ve Sears, D. O. (2015). Sosyal psikoloji (Çev. A. Dönmez). 4. Baskı. Ankara: İmge Kitabevi Yayınları.

Van Slyke, D.M. ve Brooks, A.C. (2005). Why do people give? New evidence and strategies for nonprofit managers. American Review of apaublic Adminstration, 35(3), 199-222.

Вьюнова,Н.И., Ларских, М.В. vе Стребкова, И. Н. (2014). ИнтегративноДифференцированные Аспекты Пассионарности и Перфекционизма Аичности: Диагностика, Проектирование и Развитие. Вестник Воронежского государственного технического универсиmema, 3(2), 13-20.

Ümmet, D., Ekşi, H. ve Otrar, M. (2013). Özgecilik (altruism) ölçeği geliştirme çalışması. Değgerler Ĕ̆itim Dergisi, 11, 301-321.

Warneken, F., Tomasello, M. (2008). Extrinsic rewards undermine altruistic tendencies in 20-month-olds. Development Psychology, 44 (6), 1785-1788.

Wedekind, C. ve Braitwaite, V. A. (2002). The long-term benefits of human generosity in indirect preciprocity. Current biology, 12, 1012-1015.

\section{Kaynakça Bilgisi / Citation Information}

Khalınbaylı, K. ve Taş, B. (2019). Üniversite öğrencilerinde özgecilik ve mükemmeliyetçilik anlayışı arasındaki ilişkinin incelenmesi OPUS-Uluslararası Toplum Araştırmaları Dergisi, 14(20), 1564-1593. DOI: 10.26466/opus.580182 